\title{
Pelatihan Penyusunan Bahan Ajar IPS Berbasis Spasial bagi Guru SD di SD Djama'atul Ichwan Surakarta tahun 2019
}

\author{
Mukhlis Mustofa \\ Program Studi Pendidikan Guru Sekolah Dasar \\ Universitas Slamet Riyadi Surakarta
}

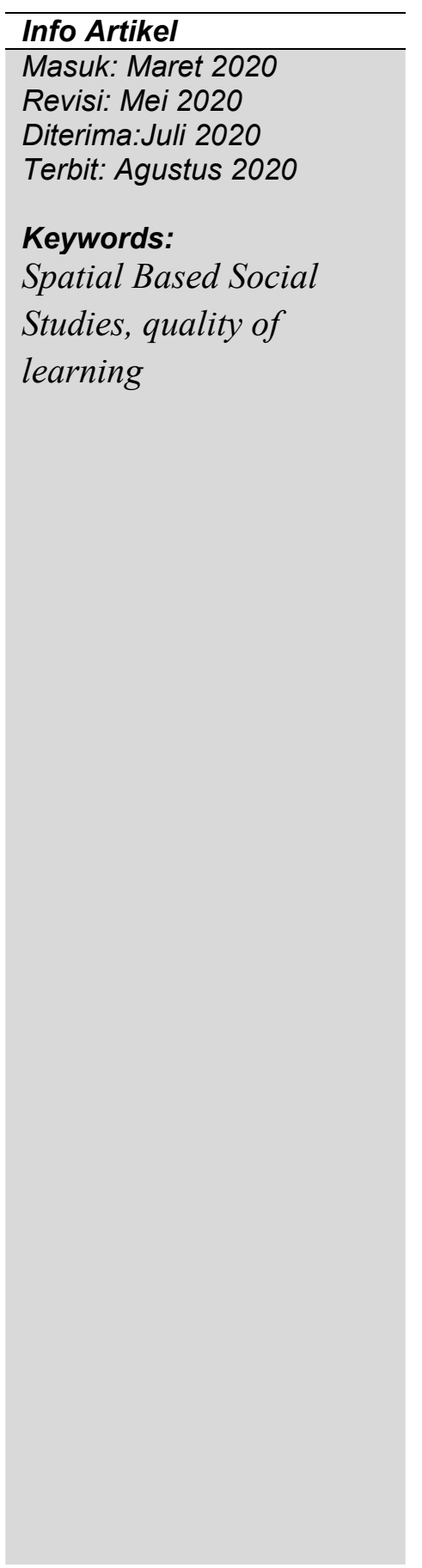

\begin{abstract}
Learning activities undertaken in classroom management determine the success of the learning process. Training on Spatial Based Social Studies Module Preparation Training for Primary School Class Teachers to Improve the Quality of Learning in SD Djama'atul Ichwan became a part of supporting learning success. Optimization of Spatial-based Learning towards improving the quality of learning will take place effectively supported by the Training Module for the preparation of teaching materials. The publishing of learning modules needs to be arranged to find out how optimal learning is done. Through Spatial-based Learning Modules, of course, you will get an accurate training guide that helps teachers to manage learning and as a guide in making decisions and following developments that have been achieved by their students. Based on surveys in the field, there is a phenomenon of the lack of spatial understanding of teachers. Therefore, the community service this time held a training program to improve the quality of learning. The aim of this service program is to provide a Training on Spatial Based Social Studies Module Development for Class Teachers in learning management to Jama'atul Ichwan Surakarta Elementary School teachers so that participants can apply school management patterns in effective and efficient management of educational institutions. The target of community service activities is aimed at Class Teachers of Jama'atul Ichwan Surakarta Elementary School Teachers as one of the solutions to overcome the problems faced in the management of learning related to inequality in this modern era. This training will help class teachers improve their teaching material preparation skills. This community service is carried out at Jama'atul Ichwan Elementary School Surakarta teacher. The method of implementing the services
\end{abstract}


Kata kunci:

disusun berdasarkan

Pembelajaran BerbasisSpasial, kualitaspembelajaran

P-ISSN: 2598-2273

E-ISSN: 2598-2281 includes: 1) preparation, 2) the implementation of the training includes the presentation of material, the assignment of making learning spatial based. The expected output target is that classroom teachers who take spatialbased learning training can improve the quality of learning and apply it themselves to their daily processes, as well as document it in the form of learning modules that can be used together for classroom teachers. It is hoped that this module can be disseminated to class teachers in other regions. classroom teachers who attend the training can also adjust according to the latest knowledge developments.

\section{Abstrak}

Kegiatan pembelajaran yang dilakukan dalam pengelolaan kelas menentukan keberhasilan proses pembelajaran. Pelatihan Penyusunan Modul Pembelajaran IPS Berbasis Spasial Bagi Guru Kelas Sekolah Dasar Untuk Meningkatkan Kualitas Pembelajaran Di SD Djama'atul Ichwan menjadi sebuah bagian untuk mendukung keberhasilan pembelajaran. Optimalisasi Pembelajaran berbasis spasial menuju peningkatan kualitas pembelajaran ini akan berlangsung efektif didukung dengan Modul Pelatihan penyusunan bahan ajar. Penerbitan modul pembelajaran perlu disusun untuk mengetahui seberapa optimal pembelajaran dilakukan. Melalui Modul Pembelajaran berbasis spasial tentunya akan didapatkan panduan pelatihan yang akurat yang membantu guru untuk pengelolaan pembelajaran dan sebagai panduan dalam pengambilan keputusan dan mengikuti perkembangan yang telah dicapai oleh siswanya. Berdasarkan survei di lapangan terdapat fenomena rendahnya pemahaman spasial guru. Oleh karena itu, pada pengabdian kepada masyarakat kali ini tim mengadakan pelatihan untuk peningkatan kualitas pembelajaran. Tujuan yang hendak dicapai dari program pengabdian ini adalah memberikan Pelatihan Penyusunan modul IPS Berbasis Spasial Bagi Guru Kelas dalam manajemen pembelajaran kepada guru SD Jama'atul Ichwan Surakarta sehingga peserta dapat menerapkan pola manajemen sekolah dalam efektif dan efisien dalam pengelolan lembaga pendidikan.

Sasaran kegiatan pengabdian masyarakat ini 
ditujukan untuk Guru Kelas guru SD Jama'atul Ichwan Surakarta sebagai salah satu solusi untuk mengatasi permasalahan yang dihadapi dalam pengelolaan pembelajaran berkaitan ketimpangan yang ada di era modern ini. Pelatihan ini akan membantu para Guru kelas dalam meningkatkan kemampuan penyusunan bahan ajar.Pengabdian masyarakat ini dilakukan di guru SD Jama'atul Ichwan Surakarta. Metode pelaksanaan pengabdian meliputi: 1) persiapan, 2) pelaksanaan pelatihan meliputi penyajian materi, penugasan membuat pembelajaran berbasis spasial. Target luaran yang diharapkan adalah Guru kelas yang mengikuti pelatihan pembelajaran berbasis spasial dapat meningkatkan kualitas pembelajaran dan mengaplikasikannya sendiri pada proses kesehariannya, sekaligus mendokumentasikannya dalam bentuk modul pembelajaran yang dapat digunakan bersama bagi guru kelas. Diharapkan modul ini dapat didesiminasikan kepada guru kelas di wilayah lain. guru kelas yang mengikuti pelatihan pun dapat menyesuaikan sesuai dengan perkembangan pengetahuan terkini.

\section{PENDAHULUAN}

Kegiatan pembelajaran yang dilakukan dalam pengelolaan kelas menentukan keberhasilan proses pembelajaran. Skill pengelolaan pembelajaran di kelas memerlukan keberlanjutan mengikuti perkembangan pembelajaran kekinian. Pelatihan Penyusunan Modul Pembelajaran IPS Berbasis Spasial Bagi Guru Kelas Sekolah Dasar Untuk Meningkatkan Kualitas Pembelajaran Di SD Djama'atul Ichwan menjadi sebuah bagian untuk mendukung keberhasilan pembelajaran. Optimalisasi Pembelajaran berbasis spasial menuju peningkatan kualitas pembelajaran ini akan berlangsung efektif didukung dengan Modul Pelatihan penyusunan bahan ajar. Penerbitan modul pembelajaran perlu disusun untuk mengetahui seberapa optimal pembelajaran dilakukan. Melalui Modul Pembelajaran berbasis spasial tentunya akan 
didapatkan panduan pelatihan yang akurat yang membantu guru untuk pengelolaan pembelajaran dan sebagai panduan dalam pengambilan keputusan dan mengikuti perkembangan yang telah dicapai oleh siswanya.

Pendidikan merupakan usaha agar dapat menghasilkan manusiamanusia yang kreatif, inovatif, terampil dan berkualitas melalui kegiatan proses pembelajaran baik yang diperoleh di sekolah maupun di luar sekolah. Menurut Undang-Undang Sistem Pendidikan Nasional Nomor 20 tahun 2003 menyatakan bahwa pendidikan adalah usaha sadar dan terencana untuk mewujudkan suasana belajar dan proses pembelajaran agar peserta didik secara aktif mengembangkan potensi dirinya untuk memiliki kekuatan spritual keagamaan, pengendalian diri kepribadian, kecerdasan, akhlak mulia, serta keterampilan yang diperlukan dirinya, masyarakat, bangsa dan negara. Selanjutnya pada pasal 19 ayat 1 tahun 2005 menyatakan bahwa proses pembelajaran pada satuan pendidikan diselenggarakan secara interaktif, inspiratif, menyenangkan, menantang dan memotivasi peserta didik untuk berpartisipasi aktif, serta memberikan ruang yang cukup bagi prakarsa, kreativitas dan kemandirian sesuai dengan bakat, minat dan perkembangan fisik serta psikologis peserta didik.

IPS merupakan ilmu untuk menunjang berbagai aktivitas kehidupan dalam segala perwujudan makna hidup sepanjang hayat, dan dorongan peningkatan kehidupan. Lingkup bidang kajiannya memungkinkan manusia memperoleh jawaban atas pertanyaan dunia sekelilingnya yang menekankan pada aspekaspek spasial ekstensi manusia, agar manusia memahami karakteristik dunianya dan tempat hidupnya. Bidang kajian IPS meliputi fenomena muka bumi dan proses-proses yang 
membentuknya, hubungan antar manusia dengan lingkungan, serta pertalian antara manusia dengan tempat-tempat. Sebagai suatu disiplin ilmu integratif, IPS bertujuan mengembangkan potensi peserta didik agar peka terhadap masalah sosial yang terjadi di masyarakat, memiliki sikap mental positif terhadap perbaikan segala ketimpangan yang terjadi dan terampil mengatasi setiap masalah yang terjadi seharihari baik yang menimpa dirinya sendiri maupun yang menimpa kehidupan masyarakat.

Mata pelajaran IPS mengembangkan pemahaman siswa tentang organisasi spasial, masyarakat, tempat-tempat, dan lingkungan pada muka bumi. Siswa di dorong untuk memahami proses-proses fisik yang membentuk pola-pola bumi, karakteristik dan persebaran spasial ekologis di muka bumi, sehingga diharapkan siswa dapat memahami bahwa manusia menciptakan wilayah (region) untuk menyederhanakan kompleksitas muka bumi. Selain itu, siswa di motivasi secara aktif untuk menelaah bahwa kebudayaan dan pengalaman mempengaruhi persepsi manusia tentang tempat-tempat dan wilayah. Dengan demikian siswa diharapkan bangga akan warisan budaya dengan memiliki kepedulian kepada keadaan sosial, proses-proses demokratis dan kelestarian ekologis, yang pada gilirannya dapat mendorong siswa untuk meningkatkan kualitas kehidupan lingkungannya pada masa kini dan masa depan.

Menurut Trianto (2010: 176-177) tujuan utama IPS ialah untuk mengembangkan potensi siswa agar peka terhadap masalah sosial yang terjadi di masyarakat, memiliki sikap mental positif terhadap perbaikan segala ketimpangan yang terjadi, dan terampil mengatasi setiap masalah yang terjadi sehari-hari, baik 
yang menimpa dirinya sendiri maupun yang menimpa masyarakat. IImu pengetahuan sosial perlu diajarkan kepada anak didik karena pengetahuan sosial diperoleh di kehidupan sehari-hari secara alamiah pada diri kita masing-masing, namun untuk menghadapi segala permasalahan dalam kehidupan bermasyarakat belum cukup. Permasalahan yang terjadi di masyarakat sudah semakin berkembang dan untuk menghadapinya tidak cukup jika pengetahuan sosial hanya diperoleh secara alamiah. Sehingga, diperlukan pendidikan IPS secara formal.

Sebagai seorang desainer dalam pembelajaran, guru sangat berperan dalam menentukan berhasil tidaknya pencapaian tujuan pembelajaran. Agar tujuan pembelajaran IPS dapat tercapai, guru di tuntut untuk memiliki keterampilan dan dapat mengorganisasikan bahan/materi sedemikian rupa sehingga bahan pelajaran menjadi menarik serta menantang. Namun saat ini terdapat kecenderungan bahwa guru sering menggunakan teknik-teknik pembelajaran IPS yang kurang memobilisasi dan menumbuhkan potensi berpikir, sikap, dan keterampilan siswa. Memahami peserta didik, merupakan sikap yang harus dimiliki dan dilakukan guru, agar guru dapat mengetahui aspirasi/tuntutan peserta didik yang bisa dijadikan bahan pertimbangan dalam penyusunan program yang tepat bagi peserta didik, sehingga kegiatan pembelajaran pun akan dapat memenuhi kebutuhan, minat mereka dan tepat berdasarkan dengan perkembangan mereka. Kalau kita amati, sistem proses pembelajaran di Indonesia masih menekankan kepada aspek inetelektual semata. Contohnya dalam pemahaman mengenai pola interaksi sosial. Para anak didik masih di tuntut dalam sistem hafalan. Sedang kita ketahui, bahwa dengan sistem tersebut, 
anak didik tidak mengetahui mengenai maksud dari pola interaksi sosial yang mereka hafalkan tersebut.

Multiple Intelligences atau multi cerdas adalah sintesis beberapa teori dan pendidikan praktis. Sintesis ini meliputi: Accelerated learning - dikembangkan pada pertengahan 1970 berdasar kerja George Lozanov, Accelerated Learning dapat didefinisikan sebagai pemberdayaan siswa untuk belajar lebih cepat, lebih efektif dan lebih menyenangkan. Materi jadi lebih bermakna dan daya ingat lebih kuat. Metode ini menggabungkan penggunaan musik, seni, dan warna sebagai fokus lingkungan fisik, suasana emosional dan pembahasan. Lozanov juga menekankan pentingnya kepercayaan kuat pada kemampuan siswa, dan inti pengajaran tampak dari model teladan. Pada intinya Multi cerdas meyakini bahwa belajar adalah proses alamiah dan setiap siswa selalu berbakat. Dengan mengembangkan kepercayaan diri siswa disertai peningkatan kemampuan akademis, dan pembinaan spiritual, Quantum multi cerdas memberi guru dan siswa segudang senjata untuk sukses. Berkaitan dengan praktik pembelajaran IPS di sekolah, guru sangat berperan dalam menentukan berhasil tidaknya tujuan pembelajaran. Idealnya dalam merancang kegiatan pembelajaran, guru harus dapat melatih siswa untuk bertanya, mengamati, menyelidiki, membaca, mencari, dan menemukan jawaban atas pertanyaan baik yang diajukan oleh guru maupun yang mereka ajukan sendiri.

Menurut Gardner (1999: 10) setiap manusia memiliki kecerdasan dengan aspek yang lebih luas sedikitnya ada 8 jenis kecerdasan yaitu kecerdasan linguistik, logika matematika, visualspatial, bodily-kinestetik, musikal, interpesonal, intrapersonal, dan naturalistik. disebut teori kecerdasan majemuk (multiple 
intelligence). Yaumi dan Nurdin (2013: 15) mengatakan bahwa kecerdasan visualspasial merupakan kecerdasan yang dikaitkan dengan bakat, seni, khususnya seni lukis dan seni arsitektur. Kecerdasan visual-spasial atau kecerdasan gambar atau kecerdasan ruang didefinisikan sebagai kemampuan mempresepsi dunia visualspasial secara akurat serta mentransformasikan persepsi visual-spasial tersebut dalam berbagai bentuk. Kemampuan berpikir visualspasial merupakan kemampuan berpikir dalam bentuk visualisasi, gambar, dan bentuk tiga dimensi.

Menurut Armstrong (2009: 7) kecerdasan spasial adalah kemampuan untuk memahami dunia visualspasial secara akurat (misalnya, sebagai pemburu, pramuka, atau pemandu) dan melakukan perubahanperubahan pada persepsi tersebut (misalnya sebagai dekarator interior, arsitek, atau seniman atau penemu). Kecerdasan ini melibatkan kepekaan terhadap warna, garis, bentuk, ruang, dan hubunganhubungan yang ada diantara unsur-unsur ini. Hal ini mencakup kemampuan untuk memvisualisasikan, mewakili ide-ide visual atau spasial secara grafis, dan mengorientasikan diri secara tepat dalam sebuah matriks spasial.

Howard Gardner dalam Multiple Intelligence for The 21st Century' (1999),, menjelaskan 8 kecerdasan yang tersimpan dalam otak manusia. Konsep kecerdasan ganda ini, bila dipahami dengan baik, akan membuat semua orangtua memandang potensi anak lebih positif. Terlebih lagi, para orangtua (guru) pun dapat menyiapkan sebuah lingkungan yang menyenangkan dan memberdayakan di rumah (di sekolah). Ike R Sugianto (dalam Zoelandari, 2009) mengatakan cerdas visual spasial adalah kemampuan memahami, memproses, dan berpikir dalam bentuk visual. Anak dengan kecakapan ini mampu menerjemahkan bentuk gambaran dalam 
pikirannya ke dalam bentuk dua atau tiga dimensi. Menurut Howard Gardner (dalam Armstrong, 2003), anak yang memiliki kepintaran visual akan dapat menyelesaikan masalah ruang (spasial). Anak mampu mengamati dunia spasial secara akurat, bahkan membayangkan bentuk-bentuk geometri dan tiga dimensi, serta kemampuan memvisualisasikan dengan grafik atau ide tata ruang (spasial). Dari hasil penelitiannya, orangorang yang memiliki kepintaran visual spasial ini lebih banyak dipengaruhi otak kanan, yaitu bagian otak yang bertugas memproses ruang.

Salah satu aspek dari kognisi adalah kecerdasan visual-spasial. Piaget \& Inhelder (1971) menyebutkan bahwa kecerdasan visualspasial sebagai konsep abstrak yang di dalamnya meliputi hubungan spasial (kemampuan untuk mengamati hubungan posisi objek dalam ruang), kerangka acuan (tanda yang dipakai sebagai patokan untuk menentukan posisi objek dalam ruang), hubungan proyektif (kemampuan untuk melihat objek dari berbagai sudut pandang), konservasi jarak (kemampuan untuk memperkirakan jarak antara dua titik), representasi spasial (kemampuan untuk merepresentasikanhubungan spasial dengan memanipulasi secara kognitif), rotasi mental (membayangkan perputaran objek dalam ruang).

Guru sebagai desainer pembelajaran harus memberikan pemahaman, memotivasi sisiwa untuk melakukan kebaruan pembelajaran demi perubahan tingkah laku sebagai ranah pembelajaran. Bagaimanakah prinsip penyusunan bahan ajar proporsional dengan mengedpankan aspek spasial menjadi tantangan guru dalam pengelolaan pembelajaran.

Bahan ajar merupakan salah satu sumber belajar. Bahan ajar adalah segala bentuk bahan yang digunakan untuk membantu guru dalam melaksanakan 
kegiatan belajar mengajar. Bahan ajar berupa bahan yang tertulis maupun bahan yang tidak tertulis. Bahan ajar yang biasa digunakan oleh guru adalah bahan ajar cetak dengan jenis buku dan lembar kegiatan siswa (LKS). Buku yang digunakan oleh guru kebanyakan adalah Buku Sekolah Elektronik yaitu buku pelajaran dari pemerintah yang sudah siap digunakan karena lebih mudah jadi guru tidak menyusun sendiri bahan ajar tersebut. Masih minim guru yang menggunakan sumber belajar yang beragam ataupun mengembangkan sumber belajar yang ada, padahal apabila guru menggunakan sumber belajar yang beragam, akan lebih memudahkan siswa dalam memahami materi. Bahan ajar sangat dibutuhkan dalam proses belajar mengajar. Bila ditinjau dari pengertian menurut garis besar, maka bahan ajar mengandung isi yang substansinya meliputi pengetahuan (fakta, konsep, prinsip, dan prosedur), keterampilan, dan sikap (nilai).

\section{Beragam keuntungan pengunaan bahan ajar diantaranya}

Dengan bahan ajar kita akan memiliki pengetahuan yang luas. Dalam proses pembelajaran tidak cukup jika hanya menggunakan satu bahan ajar. Guru perlu menggunakan beberapa bahan ajar agar bisa menambah pengetahuan siswa. Bahan ajar yang menarik akan menambah minat belajar siswa.

Dengan bahan ajar yang lengkap kita bisa mengatasi keterbatasan waktu. Dalam pembelajaran IPS terdapat pelajaran mengenai sejarah, dengan bahan ajar kita bisa menunjukkan berbagai sejarah pada siswa. Apalagi siswa di kelas bawah memiliki rasa ingin tahu yang tinggi, misalnya ada materi mengenai peristiwa alam gunung meletus, bisa ditunjukkan pada siswa melalui bahan ajar tanpa melihatnya secara langsung 
Penelitian Indriana Widya Putri Program Studi Pendidikan Guru Sekolah Dasar Fakultas Keguruan dan IImu Pendidikan Universitas PGRI Yogyakarta Pengembangan Bahan Ajar Ips Berbasis Gambar Kelas lii Sekolah Dasar Berdasarkan efektivitas penggunaan bahan ajar berbasis gambar mata pelajaran IPS di kelas III dilihat dari hasil prestasi. Hasil pretest yang dilaksanakan sebelum menggunakan bahan ajar berbasis gambar menghasilkan nilai rata-rata 45,85 dan dari hasil posttest setelah menggunakan bahan ajar berbasis gambar menghasilkan nilai ratarata 73,50 . Dilihat dari mean 73,50 yang berada pada kelas interval $67,5-82,5$ sehingga dapat disimpulkan bahwa hasil nilai posttest meningkat. Berdasarkan perhitungan gain mendapatkan hasil 0,510. Menurut indeks gain, 0,510 masuk dalam $0,3 \leq \mathrm{g} \leq 0,7$. Maka masuk dalam interpretasi sedang. Artinya bahan ajar berbasis gambar efektif untuk digunakan. Berdasarkan uraian tersebut dapat dikatakan bahan ajar berbasis gambar efektif dan dapat meningkatkan prestasi belajar siswa kelas III pada mata pelajaran IPS materi lingkungan alam dan buatan

Pengembangan bahan ajar hendaklah memperhatikan prinsisp-prinsip pembelajaran. Di antara prinsip pembelajaran tersebut adalah:

Mulai dari yang mudah untuk memahami yang sulit, dari yang kongkret untuk memahami yang abstrak,

Siswa akan lebih mudah memahami suatu konsep tertentu apabila penjelasan dimulai dari yang mudah atau sesuatu yang kongkret, sesuatu yang nyata ada di lingkungan mereka. Misalnya untuk menjelaskan konsep pasar, maka mulailah siswa diajak untuk berbicara tentang pasar yang terdapat di tempat mereka tinggal. Setelah itu, kita bisa membawa mereka untuk berbicara tentang berbagai jenis pasar lainnya.

Pengulangan akan memperkuat pemahaman 
Dalam pembelajaran, pengulangan sangat diperlukan agar siswa lebih memahami suatu konsep. Dalam prinsip ini kita sering mendengar pepatah yang mengatakan bahwa $5 \times 2$ lebih baik daripada $2 \times 5$. Artinya, walaupun maksudnya sama, sesuatu informasi yang diulang-ulang, akan lebih berbekas pada ingatan siswa. Namun pengulangan dalam penulisan bahan belajar harus disajikan secara tepat dan bervariasi sehingga tidak membosankan.

Umpan balik positif akan memberikan penguatan terhadap pemahaman siswa

Seringkali kita menganggap enteng dengan memberikan respond yang sekedarnya atas hasil kerja siswa. Padahal respond yang diberikan oleh guru terhadap siswa akan menjadi penguatan pada diri siswa. Perkataan seorang guru seperti 'ya benar' atau ,'ya kamu pintar' atau,'itu benar, namun akan lebih baik kalau begini...' akan menimbulkan kepercayaan diri pada siswa bahwa ia telah menjawab atau mengerjakan sesuatu dengan benar. Sebaliknya, respond negatif akan mematahkan semangat siswa. Untuk itu, jangan lupa berikan umpan balik yang positif terhadap hasil kerja siswa.

Motivasi belajar yang tinggi merupakan salah satu faktor penentu keberhasilan belajar

Seorang siswa yang memiliki motivasi belajar tinggi akan lebih berhasil dalam belajar. Untuk itu, maka salah satu tugas guru dalam melaksanakan pembelajaran adalah memberikan dorongan (motivasi) agar siswa mau belajar. Banyak cara untuk memberikan motivasi, antara lain dengan memberikan pujian, memberikan harapan, menjelas tujuan dan manfaat, memberi contoh, ataupun menceritakan sesuatu yang membuat siswa senang belajar, dll.

Mencapai tujuan ibarat naik tangga, setahap demi setahap, akhirnya akan mencapai ketinggian tertentu.

Pembelajaran adalah suatu proses yang bertahap dan berkelanjutan. Untuk mencapai suatu standard kompetensi yang tinggi, perlu dibuatkan tujuan-tujuan antara. Ibarat anak tangga, semakin lebar anak tangga semakin sulit kita melangkah, namun juga anak tangga yang terlalu kecil terlampau mudah melewatinya. Untuk itu, maka guru perlu menyusun anak tangga tujuan pembelajaran secara pas, sesuai dengan karakteristik siswa. Dalam bahan ajar, anak tangga tersebut dirumuskan dalam bentuk indikator-indikator kompetensi. 
Mengetahui hasil yang telah dicapai akan mendorong siswa untuk terus mencapai tujuan

Ibarat menempuh perjalanan jauh, untuk mencapai kota yang dituju, sepanjang perjalanan kita akan melewati kota-kota lain. Kita akan senang apabila pemandu perjalanan kita memberitahukan setiap kota yang dilewati, sehingga kita menjadi tahu sudah sampai di mana dan berapa jauh lagi kita akan berjalan. Demikian pula dalam proses pembelajaran, guru ibarat pemandu perjalanan. Pemandu perjalanan yang baik, akan memberitahukan kota tujuan akhir yang ingin dicapai, bagaimana cara mencapainya, kota-kota apa saja yang akan dilewati, dan memberitahukan pula sudah sampai di mana dan berapa jauh lagi perjalanan. Dengan demikian, semua peserta dapat mencapai kota tujuan dengan selamat. Dalam pembelajaran, setiap anak akan mencapai tujuan tersebut dengan kecepatannya sendiri, namun mereka semua akan sampai kepada tujuan meskipun dengan waktu yang berbeda-beda. Inilah sebagian dari prinsip belajar tuntas.

\section{METODE PELAKSANAAN}

\section{Analisis SK-KD}

Analisis SK-KD dilakukan untuk menentukan kompetensi-kompetensi mana yang memerlukan bahan ajar. Dari hasil analisis ini akan dapat diketahui berapa banyak bahan ajar yang harus disiapkan dalam satu semester tertentu dan jenis bahan ajar mana yang dipilih.

\section{Analisis Sumber Belajar}

Sumber belajar yang akan digunakan sebagai bahan penyusunan bahan ajar perlu dilakukan analisis. Analisis dilakukan terhadap ketersediaan, kesesuaian, dan kemudahan dalam memanfaatkannya. Caranya adalah menginventarisasi ketersediaan sumber belajar yang dikaitkan dengan kebutuhan.

\section{Pemilihan dan Penentuan Bahan Ajar}

Pemilihan dan penentuan bahan ajar dimaksudkan untuk memenuhi salah satu kriteria bahwa bahan ajar harus menarik, dapat membantu siswa untuk mencapai kompetensi. Sehingga bahan ajar dibuat sesuai dengan kebutuhan dan kecocokan dengan KD yang akan diraih oleh peserta didik. Jenis dan bentuk bahan 
ajar ditetapkan atas dasar analisis kurikulum dan analisis sumber bahan sebelumnya.

\section{Penyusunan Peta Bahan Ajar}

Peta kebutuhan bahan ajar disusun setelah diketahui berapa banyak bahan ajar yang harus disiapkan melalui analisis kebutuhan bahan ajar. Peta Kebutuhan bahan ajar sangat diperlukan guna mengetahui jumlah bahan ajar yang harus ditulis dan sekuensi atau urutan bahan ajarnya seperti apa. Sekuensi bahan ajar ini sangat diperlukan dalam menentukan prioritas penulisan. Di samping itu peta dapat digunakan untuk menentukan sifat bahan ajar, apakah dependen (tergantung) atau independen (berdiri sendiri). Bahan ajar dependen adalah bahan ajar yang ada kaitannya antara bahan ajar yang satu dengan bahan ajar yang lain, sehingga dalam penulisannya harus saling memperhatikan satu sama lain, apalagi kalau saling mempersyaratkan. Sedangkan bahan ajar independen adalah bahan ajar yang berdiri sendiri atau dalam penyusunannya tidak harus memperhatikan atau terikat dengan bahan ajar yang lain.

\section{DAFTAR PUSTAKA}

Amstrong, Thomas, Multiple Intelligences in the Classroom, Alexandria, Virginia: ASDC, 2009

Gardner, H., Intelegence reframed: Multiple Intelligency for the 21 th, Newyork: Basic Book, 1999.

Indriana Widya Putri , PENGEMBANGAN BAHAN AJAR IPS BERBASIS GAMBAR KELAS III SEKOLAH DASAR Program Studi Pendidikan Guru Sekolah Dasar Fakultas Keguruan dan Ilmu Pendidikan Universitas PGRI Yogyakarta

Sapiudin, Pengaruh Metode Pembelajaran dan Kecerdasan Spasial Terhadap Hasil Belajar IPA Siswa

Trianto.2010.Mendesain Model Pembelajaran Inovatif-Progesif.Jakarta: Kencana

Yaumi, Muhammad dan Nurdin Ibrahim Pembelajaran Berbasis Kecerdasan Jamak, Jakarta: Kencana Prenada Media Group, 2013.

http://abiavisha.blogspot.com/2015/06/bahan-ajar-penyusunan-bahan-ajar-bagi.html 
Raharjo, Agus. 2017. Cyber Space. Yogyakarta: Genta Publishing. (example reference from book) 